\title{
Shp2 Is Dispensable in the Formation and Maintenance of the Neuromuscular Junction
}

\author{
Xian-Ping Dong $^{\mathrm{a}}$ Xiao-Ming $\mathrm{Li}^{\mathrm{a}} \quad$ Tian-Ming Gao $^{\mathrm{a}}$ Eric E. Zhang ${ }^{\mathrm{b}}$ \\ Gen-Sheng Feng ${ }^{b}$ Wen C. Xiong ${ }^{a}$ Lin Mei ${ }^{a}$ \\ aProgram of Developmental Neurobiology, Institute of Molecular Medicine and Genetics, Medical College of

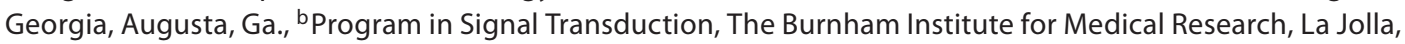 \\ Calif., USA
}

\section{Key Words}

SHP2 $\cdot$ Neuromuscular junction $\cdot$ Conditional knockout $\cdot$ Agrin $\cdot$ MuSK $\cdot$ Synapse $\cdot$ Transcription $\cdot$ Formation

\begin{abstract}
SHP2, a protein tyrosine phosphatase with two $\mathrm{SH} 2$ domains, has been implicated in regulating acetylcholine receptor (AChR) gene expression and cluster formation in cultured muscle cells. To understand the role of SHP2 in neuromuscular junction (NMJ) formation in vivo, we generated muscle-specific deficient mice by using a loxP/Cre strategy since Shp2 null mutation causes embryonic lethality. Shp2 ${ }^{\text {floxed/floxed }}$ mice were crossed with mice expressing the Cre gene under the control of the human skeletal $\alpha$-actin (HSA) promoter. Expression of SHP2 was reduced or diminished specifically in skeletal muscles of the conditional knockout (CKO) mice. The mutant mice were viable and fertile, without apparent muscle defects. The mRNA of the AChR $\alpha$ subunit and AChR clusters in CKO mice were localized in a narrow central region surrounding the phrenic nerve primary branches, without apparent change in intensity. AChR clusters colocalized with markers of synaptic vesicles and Schwann cells, suggesting proper differentiation of
\end{abstract}

presynaptic terminals and Schwann cells. In comparison with age-matched littermates, no apparent difference was observed in the size and length of AChR clusters in CKO mice. Both the frequency and amplitude of mEPPs in CKO mice were similar to those in controls, suggesting normal neurotransmission when SHP2 was deficient. These results suggest that Shp2 is not required for NMJ formation and/or maintenance.

Copyright $\odot 2006$ S. Karger AG, Basel

\section{Introduction}

Acetylcholine receptors (AChRs) are highly concentrated at the neuromuscular junction (NMJ), essential for fast and accurate neurotransmission. Two signaling pathways are believed to contribute to the enrichment of AChRs at the NMJ. Agrin, a large extracellular matrix protein, is thought to be utilized by motoneurons to form or maintain AChR clusters in the postsynaptic membrane $[1,2]$. Agrin activates MuSK, a transmembrane tyrosine kinase that is essential for agrin-induced AChR clustering [3-7]. $\mathrm{MuSK}^{-1-}$ mice, like agrin mutant mice, fail to form the NMJ $[3,8,9]$. Mutation analyses indicate

\section{KARGER}

Fax +4161306 1234 E-Mail karger@karger.ch www.karger.com (c) 2006 S. Karger AG, Basel

$1424-862 X / 06 / 0152-0053 \$ 23.50 / 0$

Accessible online at:

www.karger.com/nsg
Lin Mei

Program of Developmental Neurobiology

Institute of Molecular Medicine and Genetics, Medical College of Georgia

CB2803, 1120 15th Street, Augusta, GA 30912 (USA)

Tel. +1 706721 8775, Fax +1 706721 8685, E-Mail lmei@mcg.edu 
that the tyrosine kinase activity of MuSK is essential for its biological activity $[10,11]$. Agrin induces tyrosine phosphorylation of the AChR $\beta$ and $\delta$ subunits in a manner dependent on Src family kinases [12-18], which appears to be necessary for AChR cluster stability [19]. Recently, agrin was shown to activate Abl tyrosine kinases, geranylgeranyl transferase I (GGT), GTPases of the Rho family, and Pak1, a serine/threonine kinase that is activated by Rho GTPases [20-24]. Their inhibition attenuates agrin-induced AChR clustering [20, 21, 23, 24]. In addition, intracellular calcium and nitric oxide were shown to regulate AChR clustering [25-27].

Recent studies have identified several proteins that interact with MuSK including Dishevelled (Dvl), GGT, MAGI-1c and 14-3-3 $\gamma$ [21, 22, 28, 29]. Dvl is a signaling molecule important for planar cell polarity [21, 22]. Disruption of the MuSK-Dvl interaction inhibits agrin- and neuron-induced AChR clustering. Expression of dominant-negative Dvl1 in postsynaptic muscle cells reduces the amplitude of spontaneous synaptic currents (SSCs) at the NMJ. Dvl1 may recruit Pak1 to the complex [21]. MAGI-1c may recruit yet unidentified signaling molecules whereas 14-3-3 $\gamma$ appears to regulate synaptic gene expression via inhibition of $\mathrm{MAPK}-\mathrm{PI}_{3} \mathrm{~K}$ signaling pathways $[28,29]$.

Neuregulin (NRG) is implicated in synapse-specific transcription of AChR genes [1]. NRG acts by activating its receptor - the $180-\mathrm{kDa}$ ErbB receptor tyrosine kinases (ErbB2/HER2 [30, 31], ErbB3/HER3 [32, 33], and ErbB4/ HER4 [34, 35]). NRG induces homo- and hetero-dimerization of ErbB receptors, thus stimulating tyrosine kinase activity [36-40]. Upon activation, tyrosine residues in the carboxyl termini become phosphorylated and serve as docking sites for cytoplasmic signaling molecules such as Shc and Grb2 to activate various downstream signaling pathways [41]. Activation of ERK kinase is required for NRG regulation of AChR gene expression in muscle cells [42-44] and for synapse-specific expression of the $\varepsilon$-transgene in vivo [45]. In addition, NRG induces expression of immediate early genes $c$-jun and $c$-fos and activates the c-JUN NH2-terminal kinase (JNK), both of which are required for NRG-mediated expression of the $\varepsilon$-transgene [46]. Recently, NRG has been found to activate Cdk5, which is also required for AChR expression [47]. These results suggest that NRG activates multiple signaling cascades that converge to regulate AChR gene expression [48]. However, ErbB2 and ErbB4 double deletion in skeletal muscles form NMJs that are structurally and functionally normal in many aspects [49]. These data indicate that the NRG/ErbB signaling pathway to muscle is dispensable for at least the principal aspects of postsynaptic development.

The degree of tyrosine phosphorylation results from a balance of activities of protein tyrosine kinases that phosphorylate and phosphatases which dephosphorylate substrate proteins. However, in contrast to ample evidence for the roles of ErbB tyrosine kinases in the regulation of AChR synthesis, much less is known about the relevant protein tyrosine phosphatase(s). SHP2 (previously also known as PTP1D, SH-PTP2, Syp, or PTP2C [50-54]) is a tyrosine phosphatase that contains two $\mathrm{SH} 2$ domains. It is up-regulated during myogenesis [55] and is upregulated in response to neuregulin (NRG) [56]. SHP2 is localized at the adult NMJ [57]. Functionally, SHP2 interacts with ErbB proteins upon NRG stimulation [57]. Expression of SHP2 in muscle cells attenuates the NRG-induced expression of the $\varepsilon$-transgene, suggesting that SHP2 negatively regulates the NRG signaling pathway and may inhibit synapse-specific transcription [57]. On the other hand, SHP2 increasingly associates with MuSK in C2C12 cells in response to agrin [Camilleri et al.: Soc Neurosci, 727.1, 2005]. Treatment with pervanadate enlarges AChR clusters induced by agrin and depletion of SHP2 by siRNA increases MuSK activation and both agrin-independent and -dependent AChR clustering in $\mathrm{C} 2 \mathrm{C} 12$ myotubes [58]. These results from in vitro studies suggest a role of SHP2 in regulating AChR gene expression and cluster formation.

To investigate the role of SHP2 in NMJ formation and function in vivo, we generated mutant (CKO) mice whose SHP2 expression was attenuated or abolished specifically in skeletal muscle cells. The CKO mice are vital and fertile without apparent morphological defects in the muscle. AChR gene expression was analyzed by in situ hybridization. In addition to $\alpha$-bungarotoxin ( $\alpha$-BTX), which labels AChRs, markers of presynaptic terminals and Schwann cells were analyzed for expression and localization. Moreover, neurotransmission of the NMJs in CKO mice was analyzed by electrophysiological recording. Our results suggest that SHP2 is not essential for NMJ formation or maintenance.

\section{Materials and Methods}

Generation of Shp2 Mutant Mice

HSA-Cre transgenic mice $[59,60]$ were mated with mice heterozygous for the Shp2 floxdel allele [61]. Mice containing a HSACre and a floxdel allele were intercrossed to generate embryos with homozygous floxdel alleles and the HSA-Cre transgene. For genotyping, DNA was isolated from tails and analyzed by PCR. 
Primers for the Cre gene are: sense 5'ATG CCC AAG AAG AAG AGG AAG GT and anti-sense 5'GAA ATC AGT GCG TTC GAA CGC TAG A, which generates a 750-bp product. Primers for Shp2 floxed alleles: sense (Exo4) 5'ACG TCA TGA TCC GCT GTC AG and anti-sense (Int4AS) 5'ATG GGA GGG ACA GTG CAG TG, which generates 400 and 300 bp products from the floxed and wild-type alleles, respectively. The floxdel allele was screened using primers Int3 (sense) 5' CAG TTG CAA CTT TCT TAC CTC and NullC (anti-sense) 5' GCA GGA GAC TGC AGC TCA GTG ATG, which results in $1,000 \mathrm{bp}$ products. PCR cycles are (5 min, $\left.94^{\circ} \mathrm{C}\right) \times 1,\left(30 \mathrm{~s}, 94^{\circ} \mathrm{C}, 1 \mathrm{~min}, 56^{\circ} \mathrm{C}, 1 \mathrm{~min}, 72^{\circ} \mathrm{C}\right) \times 30$, and $\left(10 \mathrm{~min}, 72^{\circ} \mathrm{C}\right) \times 1$. The use of animals was in compliance with the guidelines of the Animal Care and Use Committee of the Medical College of Georgia.

\section{Hematoxylin-Eosin}

Diaphragms were dissected in PBS (pH 7.3) at room temperature, fixed in $4 \%$ paraformaldehyde (PFA) at $4{ }^{\circ} \mathrm{C}$ overnight, and embedded in paraffin. Sections ( $8 \mu \mathrm{m}$ thickness) were thawmounted on glass slides and treated sequentially with $2 \times 5$ min xylene, $2 \times 2 \min 100 \% \mathrm{EtOH}$, and $2 \times 2$ min $95 \% \mathrm{EtOH}$. After rinsing in distilled water, they are placed in hematoxylin (01522, Surgipath Medical Industries) for $1 \mathrm{~min}$, and rinsed first in distilled water and then in tap water for 3-5 min. Slides were rinse in $95 \% \mathrm{EtOH}$ for $30 \mathrm{~s}$ and incubated in $1 \%$ eosin (01602, Surgipath Medical Industries) for $1 \mathrm{~min}$. Slides were then dipped in $95 \%$ EtOH ten times and $100 \% \mathrm{EtOH}$ ten times, and then cleared with 3 changes of xylene for 2 min each. The slides were mounted with Permount (SP15-100, Fisher Chemicals).

\section{Whole-Mount Immunochemistry}

Whole-mount staining was performed as described previously $[62,63]$. Briefly, dissected diaphragms were fixed in $4 \%$ PFA at $4^{\circ} \mathrm{C}$ overnight, rinsed with $\mathrm{PBS}(\mathrm{pH} 7.3$ ) at room temperature, incubated with $0.1 \mathrm{M}$ glycine in PBS for $1 \mathrm{~h}$, and rinsed with $0.5 \%$ Triton X-100/PBS. Muscles were blocked in the blocking buffer (3\% BSA, $5 \%$ goat serum, and $0.5 \%$ Triton $\mathrm{X}-100$ in PBS) for $2-4 \mathrm{~h}$ at room temperature or overnight at $4^{\circ} \mathrm{C}$. They were then incubated with primary antibodies (neurofilament, 1:1,000, AB1983, Chemicon; synaptophysin, 1:2,000, A0010, Dako; SV2, 1:1,000, Developmental Studies Hybridoma Bank; S100, 1:1,000, Z0311, Dako; or rapsyn, 1:1,000) [45] in the blocking buffer overnight at $4^{\circ} \mathrm{C}$. After washing three times for $1 \mathrm{~h}$ each in $0.5 \%$ Triton X-100 in PBS, the muscles were incubated with fluorescein-conjugated anti-rabbit or mouse IgG (1:500, Molecular Probes) and Texas Red conjugated $\alpha$-BTX (RT $\alpha$-BTX 1:2,500, Molecular Probes) $2-4 \mathrm{~h}$ at room temperature or overnight at $4^{\circ} \mathrm{C}$. Samples were washed three times for $1 \mathrm{~h}$ each in $0.5 \%$ Triton X-100 in PBS, rinsed once with PBS, and flat-mounted in Vectashield mounting medium (H-1,000, Vector Laboratories). Z serial images were collected with a Zeiss confocal laser scanning microscope (LSM 510 META 3.2) and collapsed into a single image. The area and length (the longest axis) of each AChR cluster were determined with LSM 5 Image Examiner (Carl Zeiss).

\section{Acetylcholinesterase (AChE) Histochemistry}

AChE staining was performed as previously described [63]. Briefly, PFA-fixed diaphragms (see above) were rinsed 3 times in PBS and incubated in solution A ( $\mathrm{pH} 5.5$, containing $0.2 \mathrm{~mm}$ ethopropazine, $4 \mathrm{~mm}$ acetylthiocholine iodine, $10 \mathrm{mM}$ glycine,
$2 \mathrm{mM}$ cupric sulfate, and $65 \mathrm{~mm}$ sodium acetate) for $2-4 \mathrm{~h}$ at $37^{\circ} \mathrm{C}$. AChE activity was detected in situ by incubation in $1.25 \%$ sodium sulfide ( $\mathrm{pH}$ 6.5) at room temperature in a hood (for usually 2$5 \mathrm{~min}$ ). The samples were washed extensively in water and mounted in 50\% glycerol in PBS.

\section{Whole-Mount in Situ Hybridization}

In situ hybridization was performed as previously described [62]. Briefly, E18.5 diaphragms were dissected out in PBS containing $2 \mathrm{mM}$ EGTA and fixed in 4\% PFA in PBS containing $2 \mathrm{mM}$ EGTA for $1-2 \mathrm{~h}$ at room temperature or $4^{\circ} \mathrm{C}$ overnight. Samples were washed 10 min twice with PTW (PBS, 0.1\% Tween-20), once with $50 \% \mathrm{MeOH} / \mathrm{PTW}$, and once with $100 \% \mathrm{MeOH}$ and then treated with $10 \mu \mathrm{g} / \mathrm{ml}$ proteinase $\mathrm{K}$ in PTW for $30 \mathrm{~min}$ at $37^{\circ} \mathrm{C}$. After brief rinse in PTW, diaphragms were post-fixed in $4 \%$ PFA and $0.1 \%$ glutaraldehyde in PTW at room temperature for $20 \mathrm{~min}$. Samples were washed once with PTW and once with PTW/hybridization buffer (1:1) containing 50\% formamide, $1.3 \times$ SSC, $5 \mathrm{~mm}$ EDTA, $50 \mu \mathrm{g} / \mathrm{ml}$ yeast tRNA, 0.2\% Tween-20, 0.5\% 3-[(3cholamidopropyl)dimethylammonio]-1-propanesulfonate, and $100 \mu \mathrm{g} / \mathrm{ml}$ heparin. Samples were pre-incubated in the hybridization buffer for $1 \mathrm{~h}$ at $55^{\circ} \mathrm{C}$ before the addition of $1 \mu \mathrm{g} / \mathrm{ml}$ DIG-labeled RNA probe. After overnight incubation at $55^{\circ} \mathrm{C}$, diaphragms were washed in the hybridization buffer and in a 1:1 mixture of the washing solution (50\% formamide/2XSSC) and TBST $(150 \mathrm{~mm} \mathrm{NaCl}, 10 \mathrm{~mm} \mathrm{KCl}, 50 \mathrm{~mm}$ Tris, $\mathrm{pH} 7.5$, and $0.1 \%$ Tween20), each for $15 \mathrm{~min}$ at $55^{\circ} \mathrm{C}$. Samples were then incubated in TBST plus 2\% Boehringer Blocking Reagent (BBR) and 20\% heattreated goat serum for $1-2 \mathrm{~h}$ at room temperature, rinsed once with the antibody solution of TBST plus $2 \%$ BBR and $1 \%$ serum, and incubated with the antibody solution containing anti-DIGAP antibody $(1: 1,000)$ for overnight at $4^{\circ} \mathrm{C}$ or $4-6 \mathrm{~h}$ at room temperature. After rinse with TBST, samples were incubated with a solution containing $0.1 \mathrm{M} \mathrm{NaCl}, 0.1 \mathrm{M}$ Tris, $\mathrm{pH}$ 9.5, $0.05 \mathrm{M} \mathrm{MgCl}_{2}$, $1 \%$ Tween-20, $0.068 \%$ NBT, and $0.035 \%$ BCIP for color development. Samples were then washed in re-fixed in PTW with 4\% PFA and $0.1 \%$ glutaraldehyde at $4^{\circ} \mathrm{C}$ overnight.

\section{Electrophysiology}

Electrophysiological recording was performed as described previously [64]. Briefly, diaphragms with ribs were pinned on Sylgard gel in a dish and perfused with an oxygenated solution containing $145 \mathrm{mM} \mathrm{NaCl}, 5.4 \mathrm{mM} \mathrm{KCl}, 1 \mathrm{mM} \mathrm{MgCl}_{2}, 2 \mathrm{mM} \mathrm{CaCl}_{2}$, $10 \mathrm{~mm}$ Hepes- $\mathrm{NaOH}, \mathrm{pH} \mathrm{7.3}$, and $13 \mathrm{~mm}$ glucose at room temperature for at least $1 \mathrm{~h}$. Microelectrodes, 20-50 $\mathrm{M} \Omega$ when filled with $3 \mathrm{M} \mathrm{KCl}$, were placed in the central region of muscle fibers where AChR clusters were enriched. Positions were adjusted for maximal response with $\mathrm{mEPP}$ rise time smaller than $1 \mathrm{~ms}$. Data were digitized at $25 \mathrm{kHz}$ and analyzed by PCLAMP 9.2 (Axon Instruments).

\section{Western Analysis}

Western blotting was performed as previously described [65]. Nitrocellular membranes were probed with anti-SHP2 $(1: 1,000$, 610621, BD Transduction Laboratories, USA) and AChR $\alpha$ subunit (mAb35, 1:1,000). Immunoreactivity was visualized by HRPconjugated secondary antibodies (1:2,500, Pierce) and ECL reagents (Amersham Biosciences). 


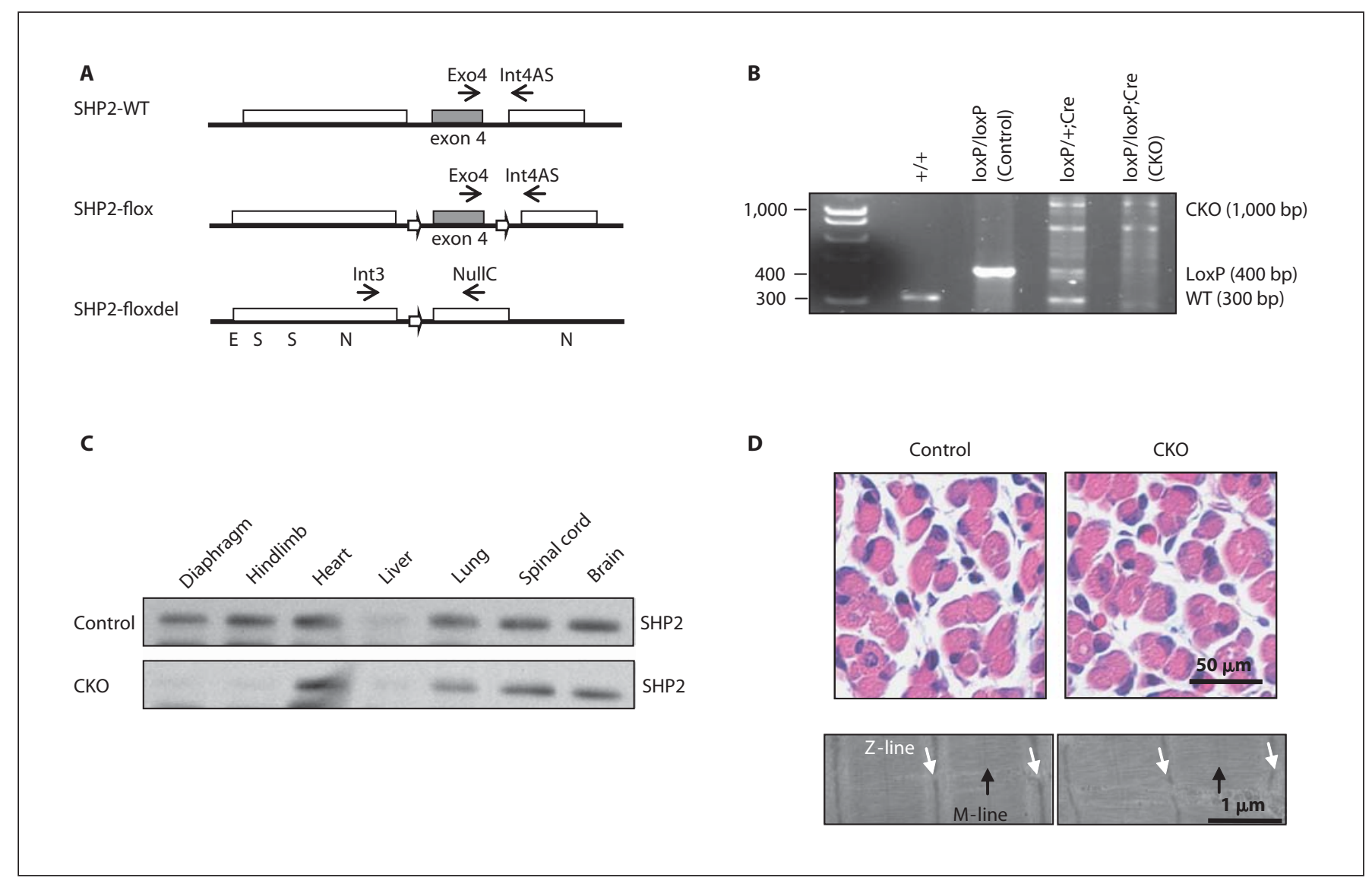

Fig. 1. Muscle-specific deletion of the Shp2 gene. A, B Different alleles of the Shp2 gene. Exo4 vs. Int 4 AS and Int3 vs. NullC are two pairs of primers for genotyping. C Western blot analysis of SHP2 levels in tissues from control (Shp2 $\left.2^{\text {loxP/loxP }}\right)$ and CKO (Shp2 $\left.2^{\text {loxP/loxP; HSA-Cre }}\right)$ mice. SHP2 expression is specifically suppressed in skeletal muscles but not other tissues in CKO mice. D Normal morphology of skeletal muscles in CKO mice. P1 muscle sections were stained with hematoxylin-eosin (top panels) or subjected to electronic microscopic analysis (bottom panels).

Fig. 2. Localization of $A C h R$ clusters in the central region of muscle fibers in CKO diaphragms. A P2 diaphragms were wholemount stained with RT $\alpha$-BTX to label the AChR (red) and with rabbit anti-neurofilament antibody to label motonerves, which were visualized by FITC-conjugated anti-rabbit antibody. Z-serial images were collected with a $\times 5$ objective using an Zeiss confocal laser scanning microscope (LSM 510 META 3.2). Images from each set of $\mathrm{z}$ series were collapsed to a single projected image. The phrenic nerve ran along the center of the diaphragm and small groups of axons leave the primary branches to innervate muscle fibers in both control and mutant mice. Shp2 deficiency did not affect the distribution of endplates. B Quantitative analysis of endplate band width.
Fig. 3. Shp2 deficiency did not affect the size and length of AChR clusters. A P15 diaphragms were whole-mount stained for AChR and nerves as in figure 2 . Z-serial images were collected with a $\times 40$ oil objective using an Zeiss confocal laser scanning microscope. Shown was a single projected image collapsed from each set of z series. Nerve terminals were found in all AChR clusters. B Enlarged images of AChR clusters of P1 and P15 diaphragms. C Characterization of AChR cluster size and length. Individual AChR clusters from one $\times 40$ field were traced around their perimeters to calculate the area and length of clusters using LSM 5 Image Examiner software (Zeiss). Both the size and length were not changed in CKO mice. 

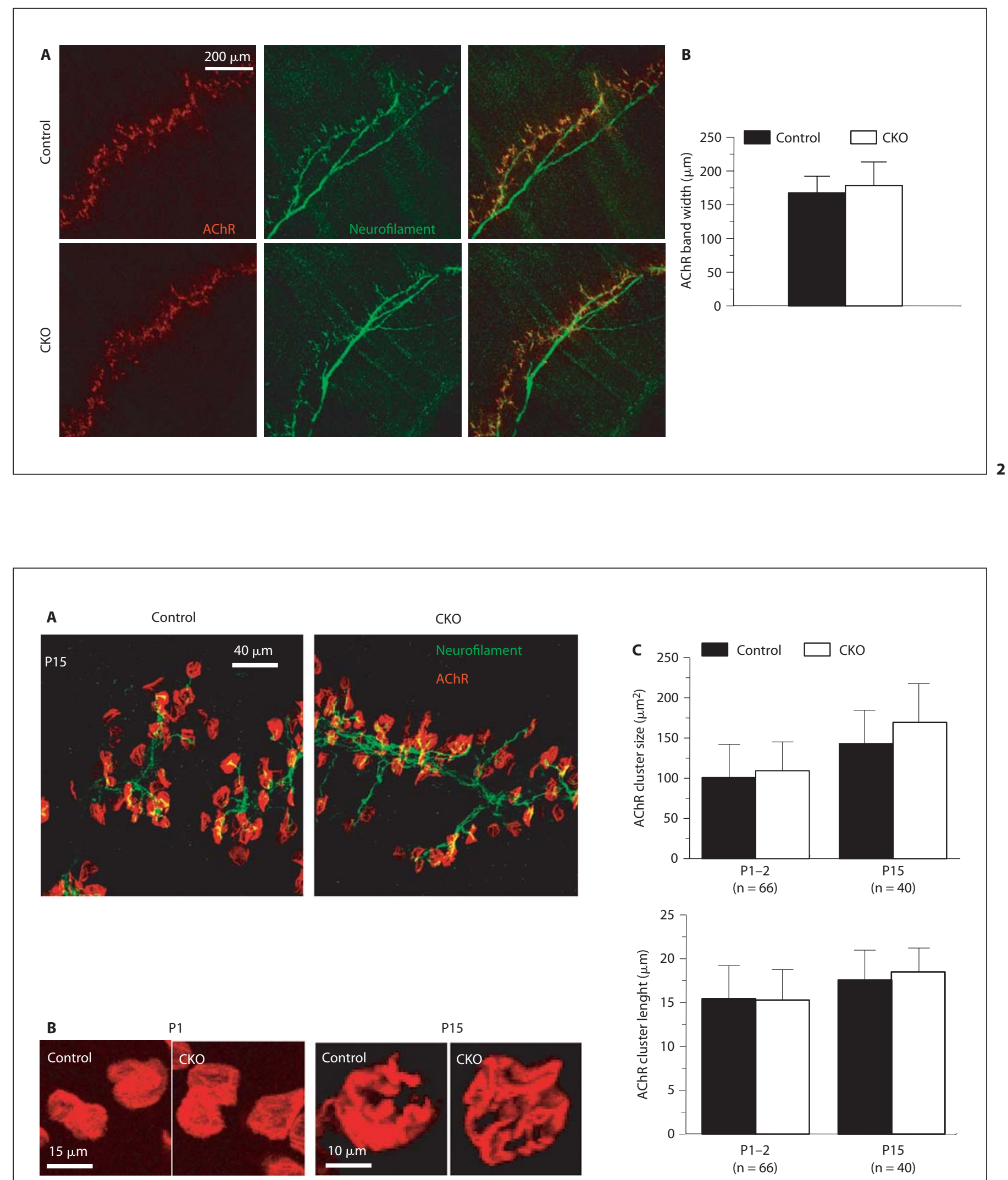


\section{Results}

\section{Shp2 Gene Inactivation in Skeletal Muscles}

To generate mice where the Shp2 gene was silenced specifically in the skeletal muscle, mice containing the floxed Shp2 allele were intercrossed with transgenic mice expressing Cre under the control of human skeletal $\alpha$-actin (HSA) promoter. This promoter was active at E9.5 in the myotomal region of somites and drives Cre expression specifically in striated muscles [59,60]. Wild-type and floxed mice generate 300- and 400-bp bands, respectively, in genotyping PCR reactions using the Exo4 and Int4AS primers (fig. 1A). In contrast, conditional knockout (CKO, i.e. Shp2 $2^{\text {floxed/floxed }}$ HSA-Cre $\left.{ }^{+/ ?}\right)$ mice generated a 1,000-bp band in genotyping PCR reactions using the Int 3 and NullC primers, which was absent in wild type (fig. 1B). Western blot analysis revealed a reduction of SHP2 specifically in muscles in CKO mice, in comparison with control littermates that include wild-type, Shp2 $2^{\text {floxed/+ }}$, and Shp2 $2^{\text {floxed/floxed }}$ mice. In contrast, SHP2 expression in other tissues was similar between control and $\mathrm{CKO}$ mice, including the spinal cord, brain, liver, and lung.

\section{Normal Muscle Morphology in Shp2-Deficient Mice}

CKO mice were vital and fertile and did not show apparent motility or behavior anonymity. At gross anatomy level, muscles of CKO mice are indistinguishable from control mice at postnatal day (P) 1, P15, and P60. Shown in figure $1 \mathrm{D}$ were representative images of $\mathrm{HE}$ staining of P1 diaphragm cross section. At the ultrastructural level, typical striated patterns were observed in both control and CKO mice. The sarcomeric organization indicated by Z-lines and M-lines was the same, if not identical, in control and CKO mice (fig. 1D). These results suggest that muscle development was unaffected in Shp2-deficient mice.

\section{Characterization of AChR Clusters in CKO Mice}

SHP2 have been implicated in regulating AChR expression and clustering, two major events in NMJ formation $[57,58]$. To determine whether SHP2 is necessary for $\mathrm{NMJ}$ formation in vivo, we first examined the band width of endplates and the size and length of AChR clusters. Diaphragms were whole-mount stained with an antineurofilament antibody to label motoneuron terminals and RT $\alpha$-BTX to label the AChR. Normally, AChR clusters are confined to a central region surrounding the primary phrenic nerve branches, forming the endplate band (fig. $2 \mathrm{~A}$, top panels) $[1,62,63]$. To analyze quantitatively the central band width, a polygon was drawn to include most peripheral AChR clusters and the average myotube length contained in the polygon was calculated. The band width was $178.3 \pm 35.0 \mu \mathrm{m}$ in CKO mice, which was similar to that in control mice $(167.6 \pm 24.3 \mu \mathrm{m}$, means \pm SEM, $\mathrm{n}=4, \mathrm{p}>0.05$ ) (fig. $2 \mathrm{~B}$ ), suggesting that Shp2 deficiency may not affect overall organization of endplate banding. The notion was supported by AChE distribution. AChE is an extracellular protein that co-locates with AChR clusters at the NMJs [66]. As shown in figure 4A, AChE activity in CKO mice was localized in a central region as in control mice.

As observed in control mice, each AChR cluster costained with the anti-neurofilament antibody in P1 and P15 CKO mutant mice (fig. 3A, data not shown), suggesting proper innervation. We measured the size and length of AChR clusters in the right ventral portion of the diaphragms of both control and CKO mice. The size of AChR clusters was similar in control and CKO mice [101 \pm $41.4 \mu \mathrm{m}^{2}$ in control and $109 \pm 36 \mu \mathrm{m}^{2}$ in CKO mice at P1 ( $\mathrm{n}=66, \mathrm{p}>0.05) ; 144 \pm 41 \mu \mathrm{m}^{2}$ in control and $171 \pm 48 \mu \mathrm{m}^{2}$ in CKO mice at P15 $\left.(\mathrm{n}=40, \mathrm{p}>0.05)\right]$. Likewise, the length of AChR clusters in CKO mice was not altered [15.4 \pm 3.8 in control and $15.4 \pm 3.4$ in CKO mice at $\mathrm{P} 1(\mathrm{n}=66, \mathrm{p}>0.05) ; 7.6 \pm 3.4$ in control and $18.4 \pm 2.8$ in CKO mice at P15 $(\mathrm{n}=40, \mathrm{p}>0.05)]$ (fig. $3 \mathrm{C})$. As the NMJ develops, AChR clusters become perforated into plaque-like structures [1]. Formation of such plaques was apparently not affected in CKO mice (fig. 3B). These results suggest that SHP2 may not be necessary for AChR cluster formation, maintenance, and/or maturation.

\section{AChR Transcripts Are Concentrated at the NMJ in CKO Mice}

In normal muscles, a few nuclei beneath the postsynaptic membrane are active in transcribing genes for NMJ formation and function [1]. For example, the mRNAs of AChR subunits are enriched in the synaptic region. To determine whether Shp2 deletion affects the spatial pattern of gene expression in muscle, in situ hybridization analysis was performed using a probe specific to the AChR $\alpha$ subunit gene. Whole-mount in situ hybridization showed that AChR $\alpha$ subunit transcripts were confined in the middle region of the diaphragms in CKO mice, like those in control mice (fig. 4B). The width of the region where $\mathrm{AChR} \alpha$ subunit transcripts are confined to and their intensity were similar in both control and CKO mice. These results suggested that AChR $\alpha$ subunit gene was transcribed properly in Shp2-deficient mice. 
Fig. 4. AChE staining and $\mathrm{AChR} \alpha$ subunit transcript distribution in $\mathrm{CKO}$ mice. A AChE activity was assayed histochemically in diaphragms of P1 mice. Images were collected with $\times 2.5$ objectives using a Zeiss microscope (Axiophot, AxioCam MRC). AChE clusters are concentrated in a center region in both control and $\mathrm{CKO}$ mice. B In situ hybridization showing AChR $\alpha$ subunit mRNA distribution in CKO mice. E18.5 diaphragms were incubated with digoxygenin-cRNA probes for the AChR- $\alpha$ subunit. Labeling was concentrated in a central band of muscle in both control and CKO mice.

Fig. 5. Normal tripartite presynaptic, postsynaptic, and glial components in CKO mice. P15 diaphragms were stained for synaptophysin, rapsyn, and S100 with respective antibodies and visualized with FITC-conjugated secondary antibodies. AChR was labeled with RT $\alpha$-BTX. Z-serial images were collected with a $\times 40$ oil objective using an Zeiss confocal laser scanning microscope. Shown was a single projected image collapsed from each set of $\mathrm{z}$ series. Synaptophysin, rapsyn and S100 were well colocalized with AChRs in both control and CKO mice.
Control
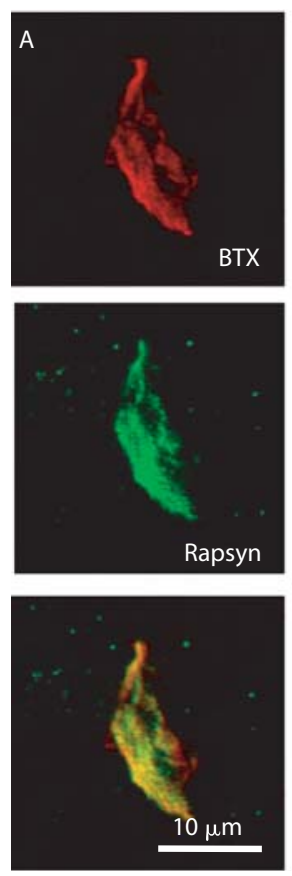

CKO
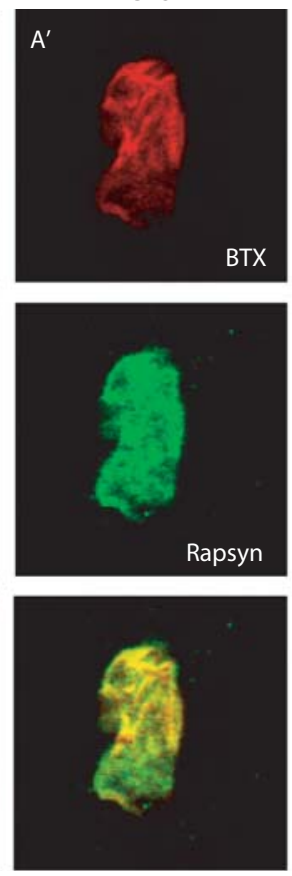

Control
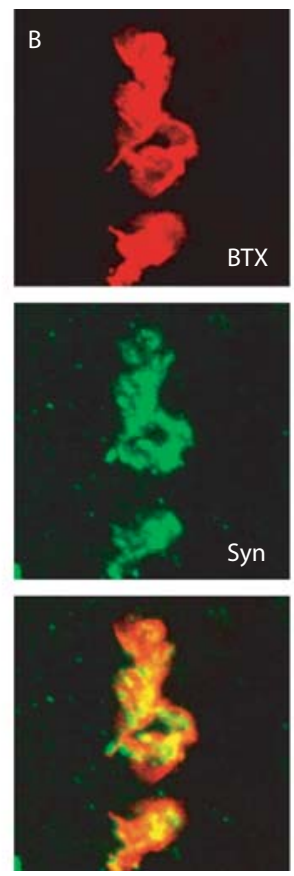

B

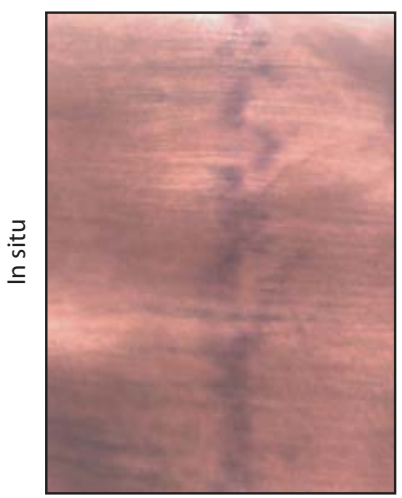

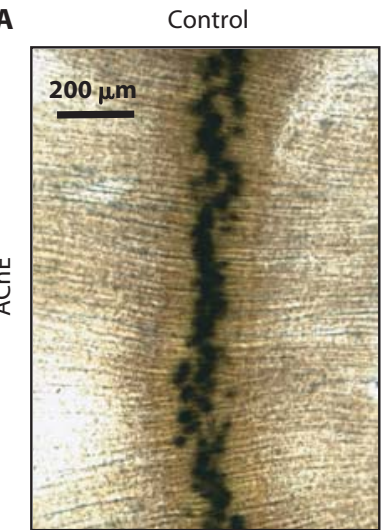

CKO

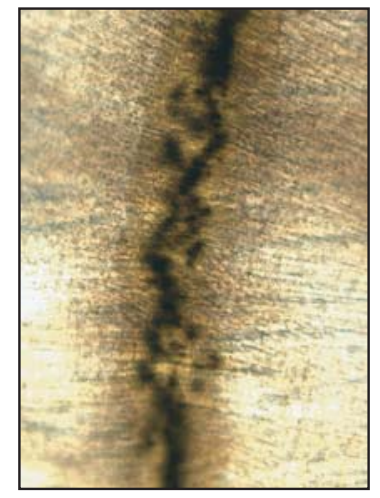

CKO

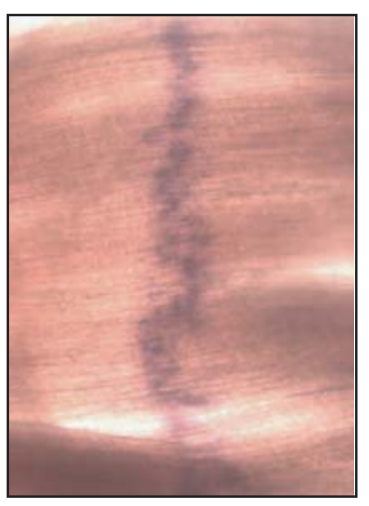

4
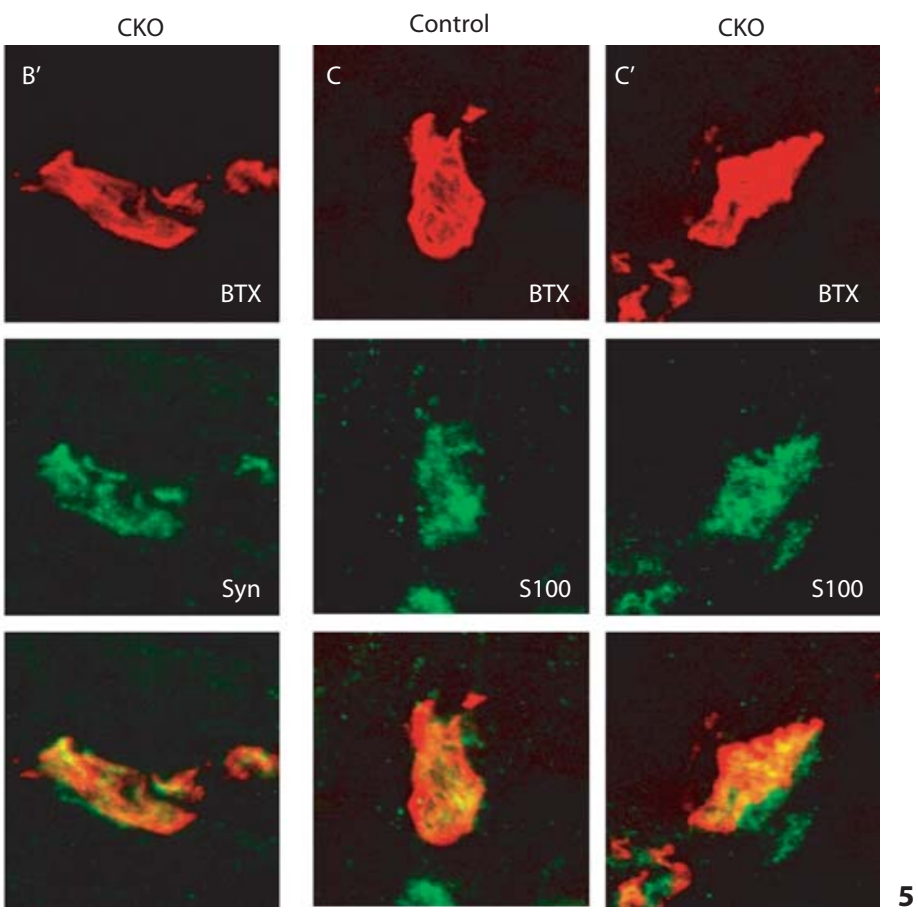


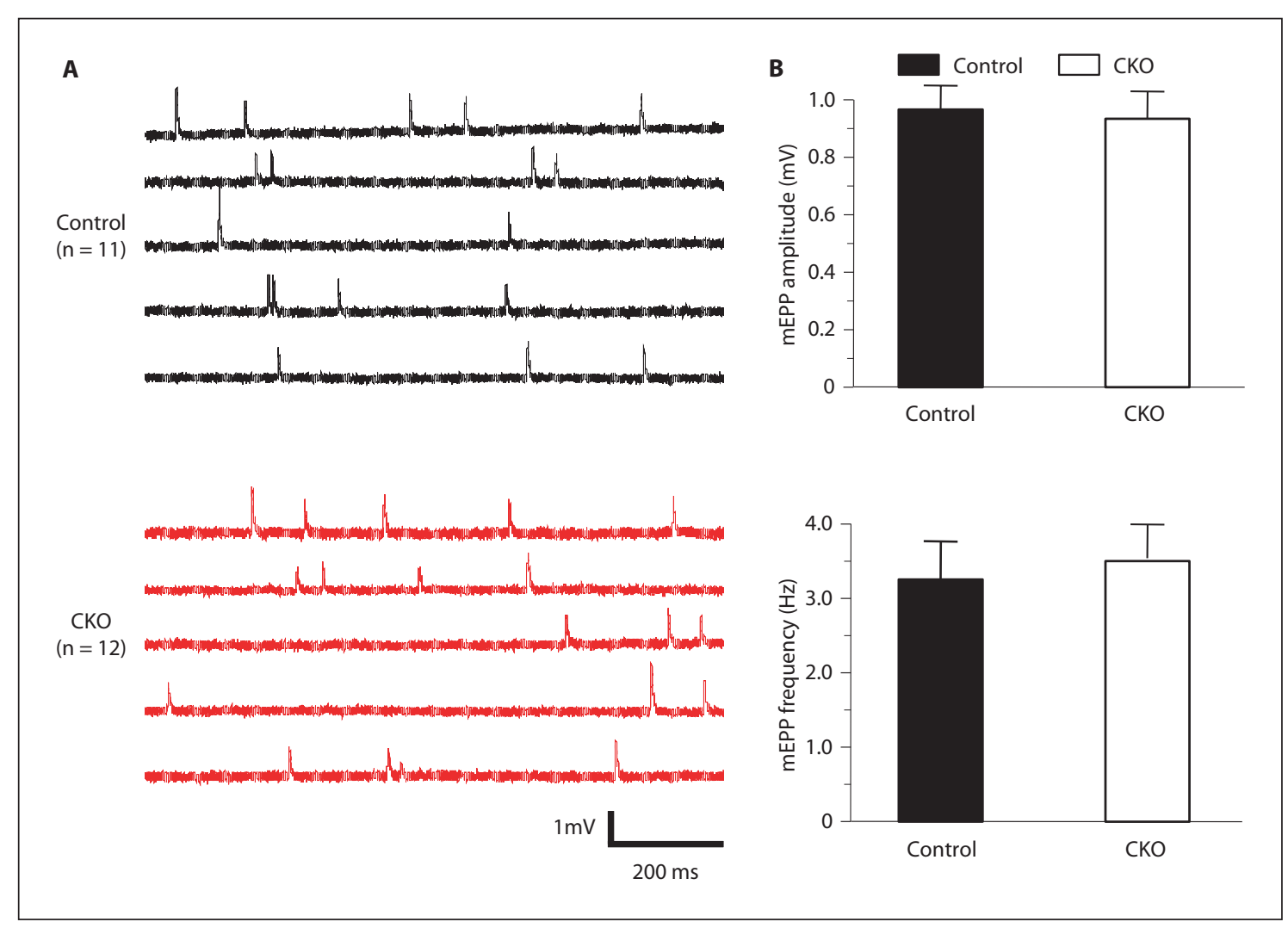

Fig. 6. Normal neurotransmission at the NMJ in CKO mice. A Representative traces of mEPPs in control (top) and CKO (bottom) mice. B Statistical analysis of the frequencies and amplitudes of mEPPs in $\mathbf{A}$.

\section{Association of AChR Clusters with Rapsyn and}

\section{Schwann Cells in CKO Mice}

The NMJ forms as a result of complex interactions among motoneurons, Schwann cells, and muscle fibers. Motoneuron terminals and perisynaptic Schwann cells are closely apposed to AChR clusters in normal NMJs. To test whether SHP2 were required to maintain both preand postsynaptic apparatus, diaphragm sections were coimmunostained with anti-synaptophysin antibody to label nerve terminals, anti-S100 antibody to label Schwann cells, and anti-rapsyn antibody to label postsynaptic apparatus. As shown in figure 5, AChR clusters were closely apposed by synaptophysin immunoreactive nerve terminals in both control and CKO NMJs. S100 staining revealed a similar pattern as synaptophysin in both types of mice, suggesting that Schwann cells were distributed in close proximity with nerve terminals. Moreover, immunostaining of rapsyn, which is colocalized perfectly with $\mathrm{AChR}$ clusters and is a key molecule for AChR clustering at the NMJ, showed that rapsyn was well colocalized with
AChR in both control and CKO NMJs (fig. 5). These results demonstrate that alignment of three components (pre- and postsynaptic and Schwann cells) was not affected by Shp2 deficiency, suggesting that Shp2 is not essential for the assembly of presynaptic and postsynaptic apparatus at the NMJs.

\section{Normal Neurotransmission at the NMJ in CKO Mice}

To characterize the function of NMJs in CKO mice, we recorded miniature endplate potential (mEPP), an indicator of vesicle fusion in the presynaptic terminals and AChR density in the postsynaptic membrane. Both the frequency and amplitude of mEPPs were similar in control and in CKO mice (fig. 6). The amplitude of mEPP was $0.96 \pm 0.08 \mathrm{mV}$ in control $(\mathrm{n}=11)$ and $0.93 \pm$ $0.09 \mathrm{mV}$ in CKO mice ( $\mathrm{n}=12, \mathrm{p}>0.05)$, whereas the frequency was $3.21 \pm 0.52 \mathrm{~Hz}$ in control and $3.47 \pm$ $0.48 \mathrm{~Hz}$ in CKO mice. These results were consistent with the above mor phological studies, suggesting normal NMJ function in CKO mice. 


\section{Discussion}

In this study, we analyzed the $\mathrm{NMJ}$ in mutant mice where SHP2 expression was specifically suppressed in the skeletal muscle. The CKO mice form NMJs that are morphologically indistinguishable from control mice. AChR clusters in CKO mice are distributed in the central region of the muscle fibers and are associated with both presynaptic terminals and Schwann cells. AChR transcripts were detectable in the sub-synaptic region in mutant mice. Moreover, the NMJ appears to be functional normally in CKO mice. These results demonstrate that NMJ or AChR clusters form and maintain properly when Shp2 is deficient. They argue against that the notion that Shp2 may be involved in regulating synapse-specific transcription and AChR clustering $[57,58]$ [Camilleri et al.: Soc Neurosci, 727.1, 2005]. It is possible that CKO mice developed a compensatory mechanism to cope with Shp2 deficiency. Many tyrosine phosphatases have been identified and more than eleven are expressed in the skeletal muscles [67]. The function of SHP2 may be compensated by one or more of these phosphatases. SHP2 shares high homology with SHP1, which also contains two SH2 domains. However, SHP1 is specifically expressed in hematopoietic cells $[68,69]$. One other possible explanation of the lack of NMJ defects in Shp2-deficient mice is the weak activity of the HSA promoter. The Shp2 CKO mice are not null mutant, although the amount of SHP2 in CKO mice was barely detectable. However, we are unable to exclude the possibility that NMJ formation and maintenance could be sufficiently regulated by the residual level of SHP2 in the mutant mice.

\section{Acknowledgements}

This work is support in part by grants from NIH (L.M. and W.C.X), Muscular Dystrophy Association (L.M.), and Philip Morris External Research Program (L.M.). We thank Dr. Rotundo for anti-AChR antibody and Dr. Melki for HSA-Cre mice.

\section{References}

- Sanes JR, Lichtman JW: Induction, assembly, maturation and maintenance of a postsynaptic apparatus. Nat Rev Neurosci 2001;2: 791-805.

-2 Gautam M, Noakes PG, Moscoso L, Rupp F, Scheller RH, Merlie JP, Sanes JR: Defective neuromuscular synaptogenesis in agrin-deficient mutant mice. Cell 1996;85:525-535.

-3 DeChiara TM, Bowen DC, Valenzuela DM, Simmons MV, Poueymirou WT, Thomas S, Kinetz E, Compton DL, Rojas E, Park JS, Smith C, DiStefano PS, Glass DJ, Burden SJ, Yancopoulos GD: The receptor tyrosine kinase MuSK is required for neuromuscular junction formation in vivo. Cell 1996;85: 501-512.

4 Burden SJ: The formation of neuromuscular synapses. Genes Dev 1998;12:133-148.

-5 Glass DJ, Bowen DC, Stitt TN, Radziejewski C, Bruno J, Ryan TE, Gies DR, Shah S, Mattsson K, Burden SJ, DiStefano PS, Valenzuela DM, DeChiara TM, Yancopoulos GD: Agrin acts via a MuSK receptor complex. Cell 1996; 85:513-523.

-6 Glass DJ, DeChiara TM, Stitt TN, DiStefano PS, Valenzuela DM, Yancopoulos GD: The receptor tyrosine kinase MuSK is required for neuromuscular junction formation and is a functional receptor for agrin. Cold Spring Harb Symp Quant Biol 1996;61:435-444.

$\checkmark 7$ Sanes JR, Lichtman JW: Development of the vertebrate neuromuscular junction. Annu Rev Neurosci 1999;22:389-442.
${ }_{8}$ Lin W, Burgess RW, Dominguez B, Pfaff SL, Sanes JR, Lee KF: Distinct roles of nerve and muscle in postsynaptic differentiation of the neuromuscular synapse. Nature 2001;410: 1057-1064.

-9 Yang X, Arber S, William C, Li L, Tanabe Y, Jessell TM, Birchmeier C, Burden SJ: Patterning of muscle acetylcholine receptor gene expression in the absence of motor innervation. Neuron 2001;30:399-410.

10 Glass DJ, Apel ED, Shah S, Bowen DC, DeChiara TM, Stitt TN, Sanes JR, Yancopoulos GD: Kinase domain of the musclespecific receptor tyrosine kinase (MuSK) is sufficient for phosphorylation but not clustering of acetylcholine receptors: required role for the MuSK ectodomain? Proc Natl Acad Sci USA 1997;94:8848-8853.

11 Zhou H, Glass DJ, Yancopoulos GD, Sanes JR: Distinct domains of MuSK mediate its abilities to induce and to associate with postsynaptic specializations. J Cell Biol 1999; 146:1133-1146.

12 Wallace BG: The mechanism of agrin-induced acetylcholine receptor aggregation. Philos Trans R Soc Lond [B] 1991;331:273280.

$13 \mathrm{Qu}$ Z, Huganir RL: Comparison of innervation and agrin-induced tyrosine phosphorylation of the nicotinic acetylcholine receptor. J Neurosci 1994;14:6834-6841.
14 Meier T, Perez GM, Wallace BG: Immobilization of nicotinic acetylcholine receptors in mouse C2 myotubes by agrin-induced protein tyrosine phosphorylation. J Cell Biol 1995;131:441-451.

15 Ferns M, Deiner M, Hall Z: Agrin-induced acetylcholine receptor clustering in mammalian muscle requires tyrosine phosphorylation. J Cell Biol 1996;132:937-944.

$\checkmark 16$ Borges LS, Ferns M: Agrin-induced phosphorylation of the acetylcholine receptor regulates cytoskeletal anchoring and clustering. J Cell Biol 2001;153:1-12.

17 Mohamed AS, Rivas-Plata KA, Kraas JR, Saleh SM, Swope SL: Src-class kinases act within the agrin/MuSK pathway to regulate acetylcholine receptor phosphorylation, cytoskeletal anchoring, and clustering. J Neurosci 2001;21:3806-3818.

18 Mittaud P, Marangi PA, Erb-Vogtli S, Fuhrer C: Agrin-induced activation of acetylcholine receptor-bound Src family kinases requires Rapsyn and correlates with acetylcholine receptor clustering. J Biol Chem 2001;276: 14505-14513.

19 Smith CL, Mittaud P, Prescott ED, Fuhrer C, Burden SJ: Src, Fyn, and Yes are not required for neuromuscular synapse formation but are necessary for stabilization of agrin-induced clusters of acetylcholine receptors. J Neurosci 2001;21:3151-3160. 
20 Weston C, Yee B, Hod E, Prives J: Agrin-induced acetylcholine receptor clustering is mediated by the small guanosine triphosphatases Rac and Cdc42. J Cell Biol 2000; 150:205-212.

-21 Luo ZG, Wang Q, Zhou JZ, Wang J, Luo Z, Liu M, He X, Wynshaw-Boris A, Xiong WC, Lu B, Mei L: Regulation of AChR clustering by Dishevelled interacting with MuSK and PAK1. Neuron 2002;35:489-505.

-22 Luo ZG, Je HS, Wang Q, Yang F, Dobbins GC, Yang ZH, Xiong WC, Lu B, Mei L: Implication of geranylgeranyltransferase I in synapse formation. Neuron 2003;40:703717.

23 Finn AJ, Feng G, Pendergast AM: Postsynaptic requirement for Abl kinases in assembly of the neuromuscular junction. Nat Neurosci 2003;6:717-723.

-24 Weston C, Gordon C, Teressa G, Hod E, Ren $\mathrm{XD}$, Prives J: Cooperative regulation by Rac and Rho of agrin-induced acetylcholine receptor clustering in muscle cells. J Biol Chem 2003;278:6450-6455.

-25 Megeath LJ, Fallon JR: Intracellular calcium regulates agrin-induced acetylcholine receptor clustering. J Neurosci 1998;18:672678.

26 Jones MA, Werle MJ: Nitric oxide is a downstream mediator of agrin-induced acetylcholine receptor aggregation. Mol Cell Neurosci 2000;16:649-660.

27 Madhavan R, Zhao XT, Chan F, Wu Z, Peng HB: The involvement of calcineurin in acetylcholine receptor redistribution in muscle. Mol Cell Neurosci 2003;23:587-599.

28 Strochlic L, Cartaud A, Labas V, Hoch W, Rossier J, Cartaud J: MAGI-1c: a synaptic MAGUK interacting with muSK at the vertebrate neuromuscular junction. J Cell Biol 2001;153:1127-1132.

-29 Strochlic L, Cartaud A, Mejat A, Grailhe R, Schaeffer L, Changeux JP, Cartaud J: 14-3-3 gamma associates with muscle specific kinase and regulates synaptic gene transcription at vertebrate neuromuscular synapse. Proc Natl Acad Sci USA 2004;101:1818918194.

-30 King CR, Kraus MH, Aaronson SA: Amplification of a novel v-erbB-related gene in a human mammary carcinoma. Science 1985; 229:974-976.

- 31 Bargmann CI, Hung MC, Weinberg RA: The neu oncogene encodes an epidermal growth factor receptor-related protein. Nature 1986; 319:226-230.

- 32 Kraus MH, Issing W, Miki T, Popescu NC, Aaronson SA: Isolation and characterization of ERBB3, a third member of the ERBB/epidermal growth factor receptor family: evidence for overexpression in a subset of human mammary tumors. Proc Natl Acad Sci USA 1989;86:9193-9197.
33 Plowman GD, Whitney GS, Neubauer MG, Green JM, McDonald VL, Todaro GJ, Shoyab M: Molecular cloning and expression of an additional epidermal growth factor receptor-related gene. Proc Natl Acad Sci USA 1990;87:4905-4909.

34 Plowman GD, Culouscou JM, Whitney GS, Green JM, Carlton GW, Foy L, Neubauer MG, Shoyab M: Ligand-specific activation of HER4/p180erbB4, a fourth member of the epidermal growth factor receptor family. Proc Natl Acad Sci USA 1993;90:1746-1750.

35 Plowman GD, Green JM, Culouscou JM, Carlton GW, Rothwell VM, Buckley S: Heregulin induces tyrosine phosphorylation of HER4/p180erbB4. Nature 1993;366:473475.

36 Tzahar E, Levkowitz G, Karunagaran D, Yi L, Peles E, Lavi S, Chang D, Liu N, Yayon A, Wen D, et al: ErbB-3 and ErbB-4 function as the respective low and high affinity receptors of all Neu differentiation factor/heregulin isoforms. J Biol Chem 1994;269:2522625233.

37 Sliwkowski MX, Schaefer G, Akita RW, Lofgren JA, Fitzpatrick VD, Nuijens A, Fendly BM, Cerione RA, Vandlen RL, Carraway KL 3rd: Coexpression of erbB2 and erbB3 proteins reconstitutes a high affinity receptor for heregulin. J Biol Chem 1994;269:1466114665.

38 Graus-Porta D, Beerli RR, Hynes NE: Singlechain antibody-mediated intracellular retention of ErbB-2 impairs Neu differentiation factor and epidermal growth factor signaling. Mol Cell Biol 1995;15:1182-1191.

39 Wallasch C, Weiss FU, Niederfellner G, Jallal $\mathrm{B}$, Issing $\mathrm{W}$, Ullrich A: Heregulin-dependent regulation of HER $2 /$ neu oncogenic signaling by heterodimerization with HER3. EMBO J 1995;14:4267-4275.

40 Graus-Porta D, Beerli RR, Daly JM, Hynes NE: ErbB-2, the preferred heterodimerization partner of all ErbB receptors, is a mediator of lateral signaling. EMBO J 1997;16: 1647-1655.

-41 Won S, Si J, Colledge M, Ravichandran KS, Froehner SC, Mei L: Neuregulin-increased expression of acetylcholine receptor epsilonsubunit gene requires ErbB interaction with Shc. J Neurochem 1999;73:2358-2368.

42 Si J, Luo Z, Mei L: Induction of acetylcholine receptor gene expression by ARIA requires activation of mitogen-activated protein kinase. J Biol Chem 1996;271:19752-19759.

43 Tansey MG, Chu GC, Merlie JP: ARIA/HRG regulates $\mathrm{AChR}$ epsilon subunit gene expression at the neuromuscular synapse via activation of phosphatidylinositol 3-kinase and Ras/MAPK pathway. J Cell Biol 1996;134: 465-476.

44 Altiok N, Altiok S, Changeux JP: Heregulinstimulated acetylcholine receptor gene expression in muscle: requirement for MAP kinase and evidence for a parallel inhibitory pathway independent of electrical activity. EMBO J 1997; 16:717-725.
45 Si J, Mei L: ERK MAP kinase activation is required for acetylcholine receptor inducing activity-induced increase in all five acetylcholine receptor subunit mRNAs as well as synapse-specific expression of acetylcholine receptor epsilon-transgene. Brain Res Mol Brain Res 1999;67:18-27.

46 Si J, Wang Q, Mei L: Essential roles of c-JUN and c-JUN N-terminal kinase (JNK) in neuregulin-increased expression of the acetylcholine receptor epsilon-subunit. J Neurosci 1999;19:8498-8508.

47 Fu AK, Fu WY, Cheung J, Tsim KW, Ip FC, Wang JH, Ip NY: Cdk5 is involved in neuregulin-induced $\mathrm{AChR}$ expression at the neuromuscular junction. Nat Neurosci 2001; 4:374-381.

48 Schaeffer L, de Kerchove d'Exaerde A, Changeux JP: Targeting transcription to the neuromuscular synapse. Neuron 2001;31:1522.

49 Escher P, Lacazette E, Courtet M, Blindenbacher A, Landmann L, Bezakova G, Lloyd KC, Mueller U, Brenner HR: Synapses form in skeletal muscles lacking neuregulin receptors. Science 2005;308:1920-1923.

50 Ahmad S, Banville D, Zhao Z, Fischer EH, Shen SH: A widely expressed human protein-tyrosine phosphatase containing src homology 2 domains. Proc Natl Acad Sci USA 1993;90:2197-2201.

51 Feng GS, Hui CC, Pawson T: SH2-containing phosphotyrosine phosphatase as a target of protein-tyrosine kinases. Science 1993; 259:1607-1611.

52 Freeman RM Jr, Plutzky J, Neel BG: Identification of a human src homology 2-containing protein-tyrosine-phosphatase: a putative homolog of Drosophila corkscrew. Proc Natl Acad Sci USA 1992;89:11239-11243.

53 Vogel W, Lammers R, Huang J, Ullrich A: Activation of a phosphotyrosine phosphatase by tyrosine phosphorylation. Science 1993;259:1611-1614.

54 Mei L, Liao K, Huganir RL: Characterization of substrate specificity of the protein tyrosine phosphatase purified from the electric organ of Torpedo californica. Neurosci Lett 1994;182:21-24.

55 Kontaridis MI, Liu X, Zhang L, Bennett AM: SHP-2 complex formation with the SHP-2 substrate-1 during C2C12 myogenesis. J Cell Sci 2001;114:2187-2198.

56 Fu AK, Cheung WM, Ip FC, Ip NY: Identification of genes induced by neuregulin in cultured myotubes. Mol Cell Neurosci 1999;14: 241-253.

57 Tanowitz M, Si J, Yu DH, Feng GS, Mei L: Regulation of neuregulin-mediated acetylcholine receptor synthesis by protein tyrosine phosphatase SHP2. J Neurosci 1999;19: 9426-9435.

58 Madhavan R, Zhao XT, Ruegg MA, Peng HB: Tyrosine phosphatase regulation of MuSKdependent acetylcholine receptor clustering. Mol Cell Neurosci 2005;28:403-416. 
59 Miniou P, Tiziano D, Frugier T, Roblot N, Le Meur M, Melki J: Gene targeting restricted to mouse striated muscle lineage. Nucleic Acids Res 1999;27:e27.

-60 Cifuentes-Diaz C, Frugier T, Tiziano FD, Lacene E, Roblot N, Joshi V, Moreau MH, Melki J: Deletion of murine SMN exon 7 directed to skeletal muscle leads to severe muscular dystrophy. J Cell Biol 2001;152:11071114.

-61 Zhang EE, Chapeau E, Hagihara K, Feng GS: Neuronal Shp2 tyrosine phosphatase controls energy balance and metabolism. Proc Natl Acad Sci USA 2004;101:16064-16069.

-62 Lin W, Sanchez HB, Deerinck T, Morris JK, Ellisman M, Lee KF: Aberrant development of motor axons and neuromuscular synapses in erbB2-deficient mice. Proc Natl Acad Sci USA 2000;97:1299-1304.
63 Lin W, Dominguez B, Yang J, Aryal P, Brandon EP, Gage FH, Lee KF: Neurotransmitter acetylcholine negatively regulates neuromuscular synapse formation by a Cdk5-dependent mechanism. Neuron 2005;46:569_ 579.

64 Brandon EP, Lin W, D’Amour KA, Pizzo DP, Dominguez B, Sugiura Y, Thode S, Ko CP, Thal LJ, Gage FH, Lee KF: Aberrant patterning of neuromuscular synapses in choline acetyltransferase-deficient mice. J Neurosci 2003;23:539-549.

65 Huang YZ, Zang M, Xiong WC, Luo Z, Mei L: Erbin suppresses the MAP kinase pathway. J Biol Chem 2003;278:1108-1114.
66 Rotundo RL: Expression and localization of acetylcholinesterase at the neuromuscular junction. J Neurocytol 2003;32:743-766.

67 Mei L, Si J: Tyrosine phosphorylation and synapse formation at the neuromuscular junction. Life Sci 1995;57:1459-1466.

68 Matthews RJ, Bowne DB, Flores E, Thomas ML: Characterization of hematopoietic intracellular protein tyrosine phosphatases: description of a phosphatase containing an $\mathrm{SH} 2$ domain and another enriched in proline-, glutamic acid-, serine-, and threoninerich sequences. Mol Cell Biol 1992;12:23962405.

-69 Neel BG, Gu H, Pao L: The 'Shp'ing news: $\mathrm{SH} 2$ domain-containing tyrosine phosphatases in cell signaling. Trends Biochem Sci 2003;28:284-293. 